\title{
THE MEANING OF BEAUTY THROUGH A WOMAN IMAGE IN STEPHANIE MEYER'S TWILIGHT
}

\author{
Itsna Syahadatud Dinurriyah \\ State Islamic University of Sunan Ampel Surabaya \\ duasyahadat@yahoo.com
}

\begin{abstract}
The presence of women has been questioned by men since ancient time up to now. They tried to define what kind of creature women are. Aristoteles had given the idea of woman that she is male in form but female in virtue. Thomas Aquinas also defined that woman is an imperfect man. In spite of their confusion about women, they like women's presence since they give beauty in life. The beauty of women is not only in men's mind but it also appears through their performance. They look so beautiful so that men want to make them as their partners in life. The meaning of beauty on women has been changed from time to time. In postmodern era, the meaning of beautiful women is not the same with that in the previous era. The elegant performance does not become the measurement anymore. The idea of what 'she becomes' is the indication of beauty itself and it is discussed in the last part of the article.
\end{abstract}

Keywords: beauty; performance; post-modern; woman image.

\section{INTRODUCTION}

Twilight Saga is a series written by Stephanie Meyer, an American female writer. She is just a new debutant in this case. As a housewife with three children, she is successful in introducing new way of fantasy story through these novels. The saga consists of five books so far, they are, Twilight (2005), New Moon (2006), Eclipse (2007), Breaking Dawn (2008), and Midnight Sun (2009). Each of them has been published every year since 2005. Even though the background of these novels is high school teenage students but the writer intends to make it for young adult; that is why most of the readers are young women.

By using myth background that is believed by American and famous in the world, the writer uses vampire (Russian/European immigrant myth), werewolf (Indian/natives American myth) and their relationship with human. She also describes this relationship in human way; even she introduces the new concept of vampire and werewolf as inhuman.

The novel of Twilight itself is made in two versions now. Since the movie got its big success and many people became aware of Twilight world, the publisher launches the movie version of the novel. So the early cover of the novel is never replaced by the movie picture because the original one still uses a picture of hands hold an apple while the movie version uses a picture of Robert Pattinson and Kristen Steward as the cover of the book.

The story of this series starts when Isabella Swan moves from Phoenix to Fork, a small town in Washington State, America. She moves there because her mother, who got divorced 
with her father, Charlie, remarried with a soccer player, Phil, and has to move from town to town but later settle in Florida. So Bella wants to stay with her father, who is alone for fifteen years.

In this place, she meets Edward Cullen, an introvert and freak, but handsome and genius student. Many girls in the school want to be his girlfriend. Unfortunately, none of them seems proper for him. No one knows that he is a vampire. His foster father is a doctor and respected by many people in the town including Bella's father, Chief Charlie Swan.

In this town, she also meets Jacob Black, a son of Billy Black, a chief of Quileute tribe. He is appointed by his nature belief being a werewolf and his father is Bella's father's best friend. As an Indian, he lives and goes to school in reservation.

Both of these boys love Bella. Even though Bella loves Edward very much, but she also has good relationship with Jacob. Having good relationship with them makes Bella knows every little thing about vampire's and werewolf's life.

The love story between Bella and Edward as vampire is interesting enough to be discussed, but this study does not expose about that. As a new comer in Fork, Bella is quite attractive for boys there. Most of her male friends want to be close to her. The attractiveness that Bella has is opposite with her motoric ability. She is very poor in sport, unstable in walking and even clumsy. She also does not try to be look so elegant. She just performs what she is; and that is the thing Edward like. Bella has different beauty from other woman Edward knows.

This study will explore a lot about the idea of beauty in Bella's performance, however, this novel is inspired by fantasy. Fantasy derives from the adjective fantastic; it is from Latin word, phantasticus, meaning that which is visible, visionary, and unreal. By that meaning, the sense that comes to us is all imaginary activity that is fantastic and all literary works are fantasies.

According to Eagleton, literary work is imaginary (2008:2), meanwhile Rosemary Jackson in her book entitled Fantasy: The Literature of Subversion, stated that fantasy, both in literature and out of it, associated with imagination and with desire that has made it an area difficult to articulate or to define, and the 'value' of fantasy seems to reside in precisely this resistance to definition, in its 'free-floating' and escapist qualities. Literary fantasies have appeared to be 'free' from many of the convention and restrains of more realistic texts. Literature of the fantastic has been claimed as 'transcending' reality, 'escaping' the human condition and constructing superior alternate, 'secondary' worlds. 
Jackson also states that modern fantasy is rooted in ancient myth, mysticism, folklore, fairy tale and romance. It seems that fantasy provides a range of possibilities out of which various combinations produce different kinds of fiction in different historical situations.

So fantasy is nothing to do with inventing another non-human world. It has to do with inverting elements of this world, re-combining its constitutive in new relations to produce something strange, unfamiliar and apparently 'new', absolutely 'other' and different.

Sartre claimed that the fantastic, in becoming humanized, approaches the ideal purity of its essence, becomes what it had been. In this case, fantasy literature has different function; it does not invent supernatural regions, but presents a natural world inverted into something strange, something 'other'. It becomes 'domesticated', humanized, turning from transcendental explorations to transcriptions of a human condition.

In short, modern fantasy is a literary work which combines some genres in one story. It shows its characteristic of being strange, different, and new without dismissing the humanity in it. Since it is talking about human, so this study emphasize the idea of human beauty through woman image in this novel.

\section{REVIEW OF LITERATURE}

\subsection{Postfeminism}

Talking about feminism means talking about women's struggle in getting their right. Feminism is a movement started in $19^{\text {th }}$ century in western countries such as England and America. This movement happened in Victorian era (the previous era) women did not have their own right economically and socially. They were not free in having friends and socialized with other people. Their social relationship had been chosen by their husbands or by their family (father). Economically they also depended on their husbands. They could not have any work since their husband were the bread winners. It they worked outside the house, it means they did not respect their husbands. In other words, they made their husband weak because they could not fulfil their wife daily need. This movement was known as feminism the first wave.

The second wave of feminism was very radical. They demanded the equality between men and women. They believed that what men could do, women also could. Therefore, lesbianism and homosexual existed in this era. It happened in the middle of $20^{\text {th }}$ century. Furthermore, this movement was supported by those who were active academically.

For the women's movement of the 1960s and early 1970s the subject of feminism was women's experience under patriarchy, the long tradition of male rule in society which silenced 
women's voices, distorted their lives, and treated their concerns as peripheral. To be a woman under such conditions was in some respects not to exist at all (Rivkin and Ryan, 2004:765). Therefore, women at the time felt oppressed by patriarchal system. To get their independency, women do the movement which was much more radical than the previous one.

It is different from the previous movement, the third wave of feminism, or it can be said post-feminism, is supported by grassroots. They have different view because they use pop culture as place to do some activities. While in the previous movement, pop culture was treated as low culture by the second wave of feminism (Mochtar, 2008:53).

For post-feminism, the movement is identical with diversity. There is no certain guidance to be feminist. A woman may become a feminist based on the understanding she believes and chooses, and based on the condition she received in her neighborhood. They also open with the diversity because of races, ethnics, religions, gender, education, as well as sexual preferences. Therefore, the activists of this wave are from various background but they are unitized because of the similar interest and ages (Mochtar, 2008: 55). Additionally, they do not treat men as their enemy instead of their partner. They think men are not the ones who oppress them anymore (56).

Post feminism expresses the intersection of feminism with postmodernism, post structuralism and post-colonialism, and as such represents a dynamic movement capable of challenging modernist, patriarchal and imperialist frameworks. In the process, post feminism facilitates a broad-based, pluralistic conception of the application of feminism, and addresses the demands of marginalized, diasporic and colonized cultures for a non-hegemonic feminism capable of giving voice to local, indigenous and postcolonial feminisms (Brooks, 1997:4).

Post feminism or some people call it 'anti-feminist', the term is now understood as a useful conceptual frame of reference encompassing the intersection of feminism with a number of other anti-foundationalist movements including postmodernism, post-structuralism and post-colonialism. Post feminism as in the case of post-colonialism and postmodernism is often used to signal a complete break in a previous range of usually 'oppressive' relations. 'Post' as used in these instances often implies that these relations have been overcome and replaced and in this context the emphasis is on a new range of temporal, political and cultural relations. This use of the concept of 'post' is highly problematic. As it is understood in this book the concept of 'post' implies a process of ongoing transformation and change (Brooks, 1997:1).

Related to post feminism, this writing tries to connect it with the main female character in Twilight, Bella. Bella is a 17- year old girl who lives in postmodern era. Her relationship with 
Edward shows that she does not want to compete Edward as the one who oppresses her. The relationship is equal between man and woman by having appropriate communication, take and give idea as well as respect each other.

Bella is not the one who demands the equality because of man's oppression, in this case Edward. She treats Edward as partner. No enemy nuance in the story.

\subsection{Postmodernism}

The term 'postmodernism' (and its cognates) is often considered by many people to the role of the media in late twentieth century capitalist societies. Whatever usage one prefers, it is clear that 'postmodernist theory' implies certain critical stances: that the attempts to explain social and cultural developments by means of 'grand narratives' (all-embracing theories or accounts) are no longer feasible or acceptable, and that ideas can no longer be closely related to a historical reality (Carter, 2006: 119-120). So, postmodernism has introduced to the recent generation that being sequence is not important anymore. They may distract the sequence by ignoring the history believed before.

By this condition, postmodernism has attracted both strong positive and negative criticism. It can be seen as a positive, liberating force, destabilizing preconceived notions of language and its relation to the world and undermining all meta-languages about history and society. But it is also seen as undermining its own presuppositions and warding off all coherent interpretation. For many it is apolitical and ironically non-committal (120).

In contemporary society and culture - postindustrial society, postmodern culture -the question of the legitimation of knowledge is formulated in different terms. The grand narrative has lost its credibility, regardless of what mode of unification it uses, regardless of whether it is a speculative narrative or a narrative of emancipation (359).

Related to the object that will be analyzed in this writing, the relationship between Bella and Edward is not so sequence. They are form different world. Bella is a human while Edward is inhuman, but they can have such a nice relationship. No one knows that Edward and his family are vampire except Bella and werewolf. It shows that grand narrative that a normal one will try to find the common spouse has been broken by this concept. Therefore, this writing exposes the uncommon thing in the novel.

\subsection{Cultural Studies}

The word "culture" acquired a new meaning in the 1960s and 1970s. Prior to that time, culture was associated with art, literature, and classical music. To have "culture" was to possess a certain taste for particular kinds of artistic endeavor. Anthropologists have always 
used the word "culture" in a much broader sense to mean forms of life and of social expression. The way people behave while eating, talking with each other, becoming sexual partners, interacting at work, engaging in ritualized social behavior such as family gatherings, and the like constitute a culture. This broad definition of the term includes language and the arts, but it also includes the regularities, procedures, and rituals of human life in communities. Culture is both a means of domination, of assuring the rule of one class or group over another, and a means of resistance to such domination, a way of articulating oppositional points of view to those in dominance. The other perspective sees culture from the bottom up and pays more attention to the way (Rivkin and Ryan, 2004:1254). It means that culture exists because there is an agreement in a society and it becomes rules for them in running their lives. The one who break the rules means break the agreement. He or she will get social punishment from society such as treating as a freak or evicting from the neighborhood.

In the domain of culture, this contestation takes the form of the struggle for meaning, in which the dominant classes attempt to "naturalize" the meanings that serve their interests into the "commonsense" of society as a whole, whereas subordinate classes resist this process in various ways and to varying degrees and try to make meanings that serve their own interests. Consciousness is never the product of truth or reality but rather of culture, society, and history (1269). From this statement, it can be concluded that culture which is an agreement in the society turns into a nature because the society tries to naturalize it so it becomes common sense for the society. If the member of society does not do the common thing, it means she or he is treated as uncommon man or unconscious.

The social norms, or that which is socially acceptable, are of course neither neutral nor objective; they have developed in the interests of those with social power, and they work to maintain their sites of power by naturalizing them into the commonsense - the only - social positions for power. Social norms are ideologically slanted in favor of a particular class or group of classes but are accepted as natural by other classes, even when the interests of those other classes are directly opposed by the ideology reproduced by living life according to those norms (1270).

Common sense in which the society tries to maintain often collides with the change of the era. Since each era has its own time, the new common sense often comes from the youngster to show their existence. If it is accepted by the society, then the common sense will change its nature. The society will use the new common change. It will happen continuously from era to era. It is really connected with what post modernism try to comprehend about. 
Dealing with the analysis of Twilight, this writing tries to compare the conventional common sense about beauty or woman image in which most of the society agree for a long time before with the new concept about it revealed in the novel. The conventional one is the dominant common sense which is believed by the society especially American people since the literary work analyzed is from America. Yet, this novel tries to propose a new concept about the meaning of beauty in woman image that is not dominant agreed by the society. It is something different that is in the process of naturalize to the society. If the nature of it happens many time it will become a common sense that finally people understand that the era has changed. Since it changes, so the concept changes also. Therefore, there is no absolute common sense of something because it stands for the era it is accepted by the society.

\section{RESEARCH METHODS}

Since this research is library one, so the data used are taken from the original writing, critical studies, articles, encyclopedia, etc. The descriptive-analytic method is used in analyzing the woman image of beauty in Twilight. This research relates to cultural studies since the literary work is popular literature. It also uses some theories which match with the analysis such as post-feminism and post modernism.

\section{DISCUSSION OF THE MAIN THEMES}

\subsection{Isabella Swan as a Woman}

DiYanni states that as readers we often come to care about fictional characters, sometimes identifying with them, sometimes judging them (1993: 54). In this case, this writing will care about Isabella Swan as the fictional character that becomes the center of the story as well as the analysis. Therefore, identifying Isabella Swan as the female main character and the focus of this research is very important.

Isabella Swan or Bella, she prefers to be called in the novel, is a 17-year-old girl who moved from Phoenix, a big city, to Forks, a small city in Washington State. She is a daughter of Chief Charlie Swan, a respected policeman in Forks. Bella, firstly, lives with her mother but then decides to live with her father. She is a product of divorced parents so she must understand with the separation between her mother and her father.

After divorced from her father, her mother moved from Forks and lives in a bigger city. She remarries with a football player who joins and moves from one club to others. The consequence of it, her mother must also move from one place to others following her husband. It makes Bella uncomfortable. Therefore, she decides to live with her father who never marries again after the divorce. 
While identifying Bella, judging her is important too. In judging her it could be by observing the action, listening to what she says and how she says, noticing how she relates to other characters and how other characters respond to her, especially to what they say about each other (Diyanni, 1993: 54). By this condition, it will know how Bella's relationship with her father.

As the one who has left his father for long time, their relationship is not good. Bella had left her father since she was 5 years old. Now she is 17 . They have never been together for 12 years. It is quite long time to make their relation a little bit awkward. When Bella was a small kid, this condition was not so worrying. Kids can mingle with anyone without hesitation. But now, Bella is a girl. The intimate relationship between a father and a daughter has an obstacle because the father must understand the psychology of his growing daughter. Besides that, when kids turn into teenagers they usually become a little rebellious.

In spite of the awkward relation between Bella and her father, Charlie is very happy having Bella with him. Before coming to Forks, Charlie told all people in Forks that his daughter will come and stay with him. He says that her daughter is so beautiful thus many people are curious about Bella. Then it becomes very reasonable when Bella really comes, many people want to know and see her. It makes Bella famous for the first time in her life. She compares with her life when she was in Phoenix. Nobody knows her. She is an ordinary girl without something special. But in Forks, she is so special. All people know her name without having introduction while she does not know who they are.

She says that she would be the new girl from the big city with a curiosity and freak (Meyer, 2005:3). It means she realizes that she will be the attentive one for people in her new place. She also understands that she must explore again about Forks since she has forgotten about it. She even can predict that people will think she is a freak because she will be quite different with common people there.

Actually Bella does not like Forks. It is not only because it is a small town but also because it is so humid. Sunshine is rarely there. It is full of rain and snow, " "I loved the sun and the blistering heat. I loved the vigorous, sprawling city" (Meyer, 2005: 1).

It proves that Bella feels uncomfortable in Forks but she endures it for her mother and father's happiness. The one she does not like again about Forks is the out of date of the youngsters. Their social life is so small as small as the town. They do not have bar. There is no disco there. The situation of the town is just simple like their life. Therefore, when her father gives her a car as a gift, she is in confusing feeling between happiness and disappointment. The car is not a car but a truck. Not a new truck but it is older than Bella's 
age. Later on she accepts it happily since it is so strong. Besides that, when she drives it to school, there are many students who drive older cars than hers. It is very different from her previous school friends. "I was glad to see that the most of the cars were older like mine, nothing flashy" (5). "It was common thing to see a new Mercedes or Porsche in the student lot" (6).

The second sentence shows that teenagers in Phoenix especially her school mates are common with luxurious cars. They compete to have the newest car and they show it to their friends. Living for 12 years in in Phoenix makes Bella a real city girl. She must try hard to adapt Forks condition especially teens social activities. She feels awkward to be noticed by other people all the time. It is not difficult for her to have friends at school. Only one person who keeps his distance to her. He is Edward Cullen. Jessica, her friend, says that Edward is not interested in girl. It seems there is no girl proper for him, Jessica continues.

Edward is a handsome boy who lives isolated with his vampire family. Then, it is logic that he does not make any relationship with his human friends. "He was leaning away from me, sitting on the extreme edge of his chair and averting his face like he smelled something bad. I sniffed my hair. I smelled like strawberries, the scent of my favorite shampoo."(Meyer, 2005:10)

Bella realizes that there is something Edward does not like about her, but she does not know what it is. She just predicts what Edward hates about her. She really understands that she is not beautiful. She is also not an elegant person. She is not sporty, clumsy, and unattractive.

"I stumbled over a book in the walking and had to catch myself on the edge of a table.

The girl sitting there giggled" (Meyer, 2005: 9).

"Remembering how many injuries I had sustained- and inflicted- playing volleyball. I felt faintly nauseated" (11)

It proves that Bella is a laughing stock for other people since she does not know how to walk stably. She got a lot of scars in her body because of falling. She is so clumsy. In sport she also does not know how to play. She is so nervous playing sport with her friend so then she hit her partner in the game. "I hit my teammate in the head with it" (13)

Besides those weaknesses, Bella also has distinctive performance. "But physically, I'd never fit in anywhere. I should be tan, sporty, and blond. I was ivory-skinned, without even the excuse of blue eyes or red hair, despite the constant sunshine" (3-4). She wants to say that she gets a gift from God with different common sense. Since she lived in a place with much sunshine, she should have darker complexion. She also should be good in sport because her environment is possible to 
do some sports. Unfortunately, she is poor at sport. She also wants to look beautiful. According to white people myth, being beautiful must have blond hair. Yet, what she has is ivory skin, blue eyes and red hair. Her physical appearance is influenced by her mother condition. Her mother is part albino (6). So, it is reasonable if the recessive gene comes to Bella.

By that condition, of course, Bella is not confident in front of Edward. Edward's behavior on her in the first meeting is not normal, but she realizes that she is not interesting enough to be close with him. "He is gorgeous" (9). "Of course he wasn't interested in me. I wasn't interesting. And he was. Interesting....and brilliant...and mysterious... and perfect....and beautiful and possibly able to lift full-sized van with one hand" (Meyer, 2005:36). Those statement proves that Bella really understands that she is not good enough to be with Edward. Edward is too good to be true for her. All good things are in Edward, while Bella has a lot of weakness.

As a clumsy girl, Bella also does not dance. When some of her male friends invite her to the party she refuses it by saying, "I'm not going to the dance at all" (33). It is not because she does not like party but because she does not get balance in dance (37). She is not like her mother who is very good in dancing.

Edward, as the interesting boy for the rest of the girls at school, does not think like the way Bella does. Indeed, in the first meeting he is not ready seeing Bella as his friend since Bella has something good in her blood. As a vampire he cannot stand on that smell but on the other side he must control himself so his presence as vampire is still as secret. In the following days, Edward tries to be nice to Bella which makes Bella so surprise.

For Edward, Bella has something unique that other girls do not have it. Bella's weakness in balancing her walk is something interesting to Edward. He makes sure for it. "Are referring to the fact that you can't walk across a flat. Stable surface without finding something to trip over?" Edward really understand Bella's clumsiness, so he says, "You are so fragile. But I am a man" (143). It means that Edward is responsible on Bella's weak part. He does not blame Bella's condition. He feels being a man if he is able to protect Bella as his girlfriend. He wants to say that she can rely on him. She will be safe by his side. Therefore, when Bella is fainted in blood check for knowing her type of blood in biology class, even though arguing with his friend -his rival actually, Edward scoops Bella to school clinic. He also asks the teacher's permission so Bella can go home earlier.

When Edward asks her to the prom, she hesitates to go there because she does not know how to dance. Like a gentleman, Edward offers his feet to be steeped on so Bella can move 
from one step to another. It seems Bella is so perfect in dancing, but they know that it is because Edward's feet movement under Bella's.

Bella's clumsiness does not make Edward embarrassed. He is happy with that. He is so entertained with it. According to Esme, Edward's foster mother, Edward never laughs even smiles before. His life is full of brooding and isolating. Since Bella comes to his life, Edward smiles all the time and mingles with his family. He also knows how to communicate with other people normally. He knows how to make joke and laugh like other people do.

Bella brings a lot of changes in Edward. His life is like a normal man. In spite of hating Bella as human, Cullens family loves her because she brings positive changing in Edward. Firstly, Edward family especially his foster parents are so worry with Edward condition. It seems he does not like his life. He does not like his gift to be a vampire. He is so lonely. That is why they are so grateful with Bella's presence in Edward's life.

Even though Bella feels unconfident in front of Edward, who is perfect, interesting and brilliant but for Edward, Bella is the interesting one. She is so different from her girl schoolmates. Usually, a girl loves to touch a little make up on her face. They like to be beautiful and cover their weakness in their facial problem by using make up. Bella does not do that. She does not try to cover her pale skin, the thing that she does not like, by using cosmetics. She is confident with her condition in unconfident feeling. She wants to be beautiful but she does not try too hard to look beautiful. That what Edward likes; and it is beautiful for Edward. He likes her because she does not cover what she has by other thing that many people think it is good. She is so different. She has different mind and does not mind with the differences.

From the description above, there are 2 (two) things that Edward likes from Bella. The first, in spite of her unbalances through her walking, dancing or doing sport, she does not attempt to hide it. She tells the truth to anybody. It makes other people aware if they have to do something together with Bella. She does not try to make good image that she is good enough in anything because she does not want other people know her weaknesses. She gives vivid description of her image so people do not hope much to her. She has done the best for herself by hoping that no one will laugh to her clumsiness. But unfortunately, her clumsiness often makes other people laugh to her including Edward.

The second, Bella does not like her physical appearance. She does not like the color of her complexion, she does not like the color of her hair as well as her eyes. Despite that, she does not try to hide it or fix it by cosmetics. She never wears make up on her face. She goes anywhere with her bare face. Again, she is confident with her condition in unconfident 
feeling. For her, without make up is freer than cover her face so people do not recognize her well.

These two things are really worth for Edward. He is the famous one since he is handsome, brilliant, and perfect. Yet, he falls in love with Bella not because Bella is interesting, beautiful in term of attractive, or even famous. Bella is an ordinary girl without something special. She becomes so special for Edward because she performs what she has. She is different and it is what she has. She does not have to be such elegant to have a perfect boyfriend because her boyfriend is quite falling for her because of her special commonness.

\subsection{The Conventional Beauty Meaning on Woman}

Twilight is a literary work written by an American writer, Stephanie Meyer. Since it is an American work, so the paradigm is also using American concept, in this case the concept of woman beauty. Body image and great physical appearance receives great emphasis in American culture. Being thin is beautiful for woman and being muscled is handsome for man (Tom, 2005:458).

Dealing with the literary work, there is no certain information about Bella's weight. Yet, there is no information also that she has problem with her body. It can be concluded that Bella's weight is normal, she is not thin neither fat. It means, it is difficult also to say that she is beautiful. It is different from Edward. He is clearly muscled. Her face is beautiful. He is perfect. Of course he is handsome.

Being handsome or beautiful is a questioning for many people since long time ago. There is a reason why we perceive something as beautiful: Physical human beauty is linked to evolutionary patterns, such as the scheme of childlike characteristics, or the advertence of the primary and secondary sexual organs. Other traits, like tanned skin or body weight, depend on our education and culture and so are changing over time (Donne, 2010:88). So, being thin and muscled are education and culture in America. It is naturalized to people there so it becomes common sense there.

So then, what is beauty actually? Plato said that the good is always beautiful. But, what is good? Just good? Conventional ideas of prettiness were jettisoned along with the traditional feminine lore of cosmetics (Hebdige1979:107). Different from Hebdige, Donne argues that beauty is a pleasurable feeling that rises in the perception of each individual (2010:90). She explains that a particularly interesting area is the perception of beauty, because beauty has to do with the fields emotion, motivation, cognition, thinking and learning at the same time (cf. D“orner in Halcour, 2002). In order to explain the phenomenon of beauty, one must consider 
all those psychological factors and their interactions. Beauty defies categorization into one of the psychological sub-disciplines, because it covers as a process the whole human experience. Thus, it is impossible to give a meaning of beauty if one never experience the process of life. Donne opposes that beauty is only about face and body. She prefers to believe that it is related to the inside condition of people and the journey of her life.

\subsection{The Postmodern Perspective on Woman Beauty}

In Ode on a Grecian Urn, Keats writes that "Beauty is truth, truth beauty-that is all." And Emerson describes beauty as the mark God sets upon virtue." Both of them never mention physical traits to find the beauty. Keats only said that beauty only requires the truth. If someone does not manipulate his or her existence, it means she is beautiful. She does not need to wear make up to cover her facial features weakness. As long as she performs with what she is, it means she is beautiful.

The thing Keats says about beauty just like what happens to Bella. She tells the truth. She does not hide anything, physically, psychologically as well as mentally. Physically she does not wear make-up even she does not like her complexion. She does not dye her hair like what a beautiful girl should have. Psychologically, she also does not hide her weakness in sport and dancing. She just tells the truth that she is not going to dance at all and she also reveals that she hits her friend's head in volley ball. Mentally, she says that she is bad in balancing her walking. She is so clumsy. She just tells the truth like what Keats says. So, she is beautiful based on Keats concept.

Emerson also wanted to say that beauty is nothing to do with physical performance. Like what Donne says previously that beauty is related to the feeling, emotion and thought, Emerson also emphasizes that being virtue is the beauty. To have virtue needs process and the process itself is for the whole human life.

Bella is a young girl. To be virtue she needs long process. Fortunately, she is a kind person. She is friendly to all her friends. She is also loyal. When Edward does not want to tell the truth about his strength, she never demands it in front of their friends. She just waits until Edward tells her frankly. She is also very independent. She does not like if she relies on other people too much.

What Bella has so far is beyond what people think of beauty but the readers like to imagine this fictional character. The readers even can get the feel on how if they have a friend like Bella. She must be a nice person. Being nice becomes preference by many people better having beautiful physical traits but poor in behavior. 
It could be those which Edward likes from Bella. He thinks she is beautiful because of her truth and virtue. He does not need an exact beautiful girl to be this perfect guy's girlfriend. He sees the beauty in her.

Postmodern, indeed, opposes the common sense. It does not follow the mainstream held by many people, including the meaning of beauty. Like what Hebdige states that the meaning of subculture is, then, always in dispute, and style is the area in which the opposing definitions clash with most dramatic force (1979:3). Postmodern society always perform something different and they also try to find something new which is different from other people. The post-modernist always tries to oppose the common sense in society and rejects the agreement naturalized in the society. In short, they do not like hegemony as well as domination.

What Edward chooses on girl in the novel is very postmodern. He chooses Bella who does not have the criteria of beautiful conventionally. Bella is just an ordinary girl. Physically she is not attractive. Her complexion is too pale, she is not sporty and not blond. She also has problem with her balance. As a teenager she is not like the others who know how to dance well. It seems she is so freak. Nothing interesting about her physically. Edward oppose the concept of conventional beauty by falling in love to Bella. He wants to be Bella's man. He is not attracted by physical beauty, but he is so tempted by the beauty of truth just like what Keats said in his poem.

Although Bella is an ordinary girl but she does not cover her weaknesses. She does not wear cosmetics even though her skin is ivory-colored. She does not dyed her hair to be blond. She also does not try to keep her image to be so elegant by knowing many things such doing sport and dancing. She tells the truth to Edward that she is weak in balancing. She is often tripped on while she is walking. That is the truth while other people try to hide it. And it is beautiful for Edward.

Indeed, the idea of beauty is really cultural. If in America being blond is beautiful, in other countries will be different. If in America this is beautiful, in other culture in would be different. The difficulty in defining beauty is that it is ever-changing, and what is judged to be beautiful today may not be so tomorrow (Schulman, 2008:16). It is what we call postmodern; everything tries to be opposed since finding the truth is still in the process.

\section{CONCLUSION}

Beauty is something adored by all women around the world. Physically, it is very easy to define beauty. Unfortunately, not all people agree with that opinion. Some of them prefer to 
define it as something undefined. Confucius said that everything has its beauty but not everyone sees it.

What Confucius stated seems so match with what Edward sees in Bella. As an ordinary girl, Bella has beauty and only Edward can see it. Physically she is not the one adored by many men. She is not sporty, poor in dancing and has difficulty in balancing her body. Those are not characteristic of a beautiful woman. Those are the weaknesses that should be hidden in front of men. But Bella does not do that.

Bella gives Edward pleasure by her weakness. It is a kind of entertainment so than Edward can smile even laugh. As a perfect man, Edward prefers having Bella as his girlfriend. Even though she is just too common for a girl but Edward can see the goodness in Bella. She can make Edward better his social life.

The indication of a beautiful girl is changing time to time. It relates to the culture believed by certain society. When it is naturalized by the society then it will become a common sense for all. Yet, every era has its own characteristic, including the meaning of beauty. Some culture believe that being a prominent girl is beautiful, but now, being thin is much better. In the past, to be a good woman she must perform elegantly in front of other people, but now, a girl can socialize with other people with a bare face - without make up at all.

In postmodern era, the era in which people are questioning to the confirmed common sense, the meaning of beauty is also questioning. Most of them try to oppose the idea of beauty has been explained before. For modern people, beauty is related to cosmetics, but for posmo people the meaning is questioning. What Edward has done is really posmo. He opposes the conventional concept of beauty by choosing Bella as an ordinary girl. For him she is beautiful. Indeed, postmodern does not demand the quick answer because it believes that anything in still in process.

\section{REFERENCES}

Arimbi, D.A. (2009). Reading Contemporary Indonesian Muslim Women Writers. Amsterdam University Press.

Barker, C. (2008). Cultural Studies: Theory and Practice. London: Sage Publication Ltd.

Barker, M. and Beezer, A. Ed. (2005). Reading into Cultural Studies. Taylor \& Francis e-Library.

Bodgan, R.C. (1992). Qualitative Research For Education. Needham Height, A division of Simon and Schuster, Inc.

Brooks, A. (1997). Post feminism: Feminism, Cultural Theory and Cultural Forms. London: Routledge. 
Carter, D. (2006). Literary Theory. Great Britain: Pocket Essentials.

Culler, J. (1997). Literary Theory: A Very Short Introduction. Oxford: Oxford University Press.

D'Agostino, H. E., Nancy Orbach, S. and Scott, J. (2004). The Real Truth about Beauty: A Global Report. A Unilever Beauty Brand. September.

DiYanni, R. (1993). Literature: Approaches to Fiction, Poetry, and Drama. New York: The McGraw-Hill companies.

Donne, V.D. (2010). How Can We Explain Beauty? A Psychological Answer to Philosophical Question. Proceedings of the European Society for Aesthetics, vol. 2. Page 88-99

Eagleton, T. (2008). Literary Theory. The University of Minnesota Press.

Goodwin, Andrew (1991) Popular Music and Postmodern Theory. Cultural Studies. Vol. 5 No. 2, May.

Hebdige, D. (1979). Subculture The Meaning of Style. London: Routledge.

Heisenberg, W. (1970). The Meaning of Beauty in the Exact Sciences. Munich: The Bavarian Academy of Fine Arts.

Meyer, S. (2005). Twilight. New York: Little Brown.

Mochtar, J. (2008). Membaca Ideologi Jender Dalam Chick Lit Inggris dan Indonesia. Jakarta: Universitas Indonesia.

Rivkin, J. and Ryan, M. Ed. (2004). Literary Theory: An Anthology. United Kingdom: Blackwell Publishing, Ltd.

Robins, Derek (1993). Ways of knowing Culture: Williams and Bourdeiu.Cultural Studies, Vol. 7 No. 3.

Schulman, M.R. (2008 Sep/Oct). Beauty Defined. Medical Aesthetics. Page 14-16

Snograss, M.A. (2006). Encyclopedia of Feminist Literature. Facts on File. New York.

Surakhmad, W. (1989). Pengantar Penelitian Ilmiah: Dasar, Metode dan Tehnik. Bandung: Tarsito.

Tom, G., Chen, A., Liao, H., Shao, J. (2005). Body Image, Relationship and Time. The Journal of Psychology, Vol. 139 No.5. Page 458-468

Wellek, R. and Warren, A. (1948). Theory of Literature. United States: Harcourt, Brace and Company. 